\title{
Ecologically Safe Geothermal Energy Resources in Western Siberia near high-rise construction zones
}

\author{
Alexandr Shevchenko ${ }^{1,{ }^{*}}$ and Olga Shiganova ${ }^{2}$ \\ ${ }^{1}$ Novosibirsk State University of Architecture and Civil Engineering, 630008 Novosibirsk, Russia \\ ${ }^{2}$ Siberian Research Institute of Geology, Geophysics and Mineral Resources, 630008 Novosibirsk, \\ Russia
}

\begin{abstract}
The development of geothermal energy in combination with other renewable energy sources (the sun, the wind) will help to solve the problem of heat supply and electrification in near high-rise construction zones of the country, especially in sparsely populated parts, where centralized energy and heat supply is economically unacceptable, and will improve the ecological situation. The aim of the research is to analyze the geothermal resources of the main aquifers in Western Siberia and to develop recommendations for further study and use of heat and power resources of this territory. The article gives retrospective of state research programs and potential use of hydrothermal resources of administrative units geographically entering the territory under consideration. It is noted that by now such programs have been curtailed for various reasons, although there are examples of their successful and effective use in various fields of industry and agriculture. According to the decision of the Supreme Ecological Council of the State Duma Committee of the Russian Federation adopted in 2014 on the beginning of the development of federal targeted programs for the use of heat power water as a source of electricity and heat supply, the Ministry of Natural Resources and Ecology of the Russian Federation made proposals for further research and use of hydrothermal waters in Western Siberia. Implementation of the programs proposed by the authors, alongside with other positive aspects, will solve the problems of heat supply in remote territories and improve the environmental situation in the region.
\end{abstract}

\section{Introduction}

Nowadays the energy industry of Russia mainly uses traditional fossil fuels, such as oil products, natural gas and coal. Inexhaustibility and environmental cleanliness of renewable energy sources make it necessary to carry out intensive study of the prospects and ways of their usage.

\footnotetext{
* Corresponding author: michmacha@mail,ru
} 
Western Siberia is a huge, mostly sparsely populated territory, occupying about $15 \%$ of the territory of Russia. Its subsoil, along with organic fuel resources, contains significant reserves of fresh and mineral waters, waters suitable for industrial extraction of valuable chemical elements and compounds, as well as thermal and subthermal waters (fig.1).

At present the energy industry of Russia mainly uses traditional non-renewable sources, such as oil products, natural gas and coal. However, in the coming decades depletion of hydrocarbon reserves is projected. According to some estimates, taking into account world oil consumption, these reserves will last for 28 years and in Russia - only for 15 years [2].

Inexhaustibility and environmental cleanliness of renewable energy sources make it necessary to research prospects and ways of using them. The main renewable source is hydropower. The geothermal energy market has tremendous potential, since this kind of energy source is much more stable if compared to other renewable energy resources.

Today the majority of countries use geothermal heat to a certain extent [3]. Depending on its temperature, the geothermal energy heat transfer agent is used for power generation, heating of buildings, greenhouses, swimming pools, fisheries, as well as for balneological purposes [4]. There are several reasons for poor development of geothermal energy in Russia. Reserves of the majority of the country's geothermal deposits have low and medium temperatures, which currently do not allow them to be competitive with traditional energy sources.

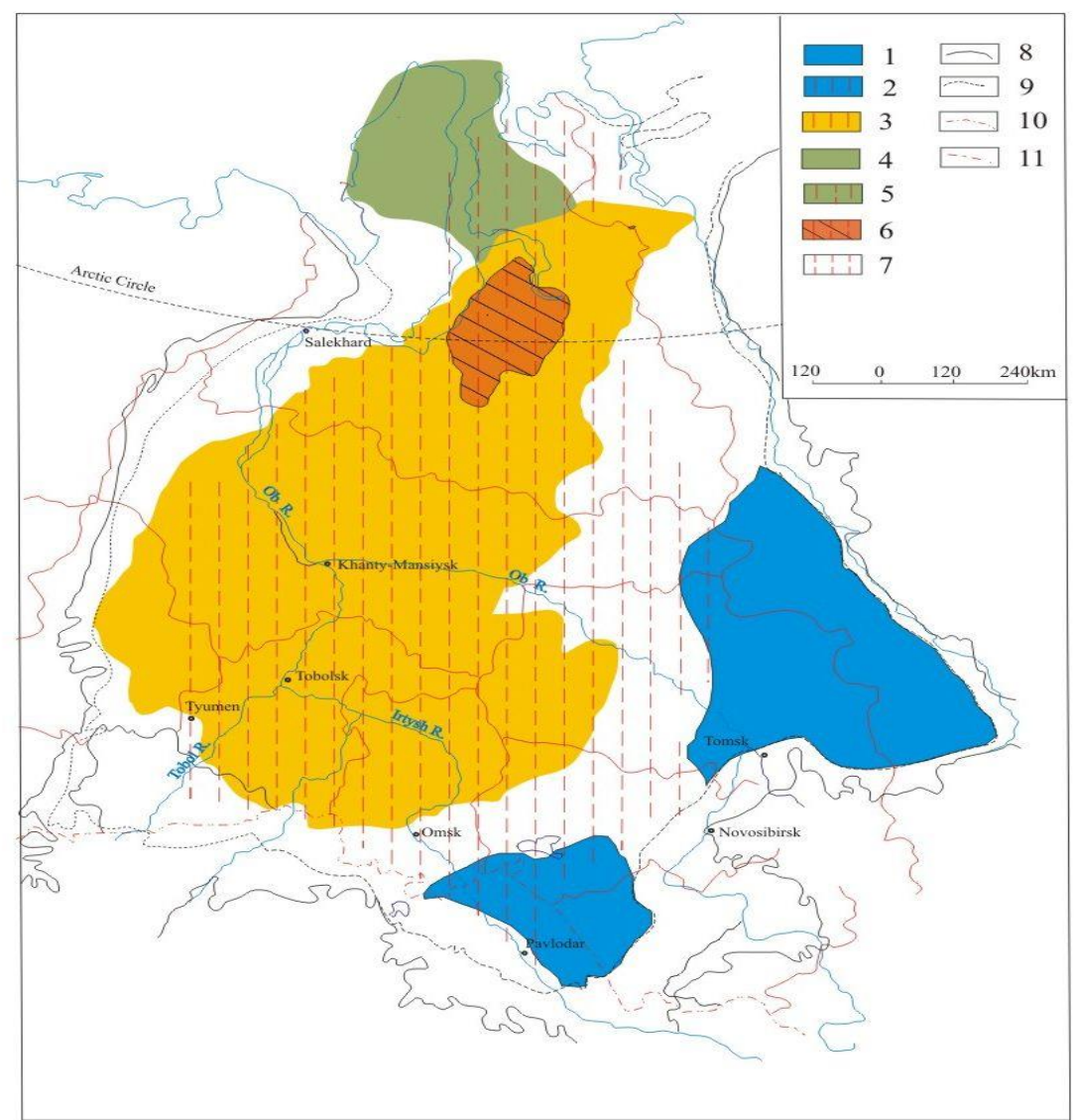

Fig. 1. Zonation of West Siberian Artesian Basin Aquifer Complex $\left(\mathrm{K}_{1-2}\right.$ Cenomanian-Aptian Pokur Formation and its Analogues)[1]. 
Area of Water Distribution:1-Fresh (Up to $1 \mathrm{~g} / 1)$; 2-Fresh Subthermal $\left(20-50^{\circ} \mathrm{C}\right)$; 3 Iodine-bromine Mineral and Thermal; 4-Iodine Mineral; 5-Iodine Mineral and Thermal; 6Industrial Iodine and Thermal; 7- Mineral Subthermal. Boundaries: 8-West Siberian Artesian Basin; 9-Aquifer Complex; 10-RF Administrative Regions, 11- Russia.

Other reasons are lack of methodological, technological and regulatory support for the extraction and the use of geothermal resources under Russian climatic conditions, lack of attention paid to environmental aspects of energy production.

In 2014 according to the decision of the Supreme Ecological Council of the State Duma Committee of Russia, the Ministry of Natural Resources and Ecology of the Russian Federation was given the task to initiate the development of federal targeted programs for the use of heat-power water as a source of electricity and heat [5]. In this regard, the analysis of the existing programs and potential use of geothermal energy in administrative units geographically located on the Western Siberia territory, as well as the experience of other regions of Russia, is particularly important. The analysis of their implementation experience will help to develop recommendations for the programs planned.

\section{Energy potential of thermal waters of Western Siberia}

Despite the huge heat potential of groundwater in different regions of Russia, their resources were not considered as the primary sources of geothermal energy even in geographical areas not provided by traditional sources. The history of studying thermal energy resources of the region's underground waters is considered in [6]. For northern and central regions of Western Siberia, the studies were carried out on the materials of testing deep wells drilled for oil and gas. In southern regions, which were not objects of large-scale study of subsurface resources for hydrocarbons, data on wells for domestic and drinking water supply were mainly used. From the hydrogeological point of view, the territory of Western Siberia is a huge artesian basin with several hydrogeological complexes (Fig.2). This basin is a huge reservoir of groundwater, which can fully meet the needs of domestic and drinking water supply, balneology, chemical industry and serve as a source of geothermal energy $[8,9]$.According to

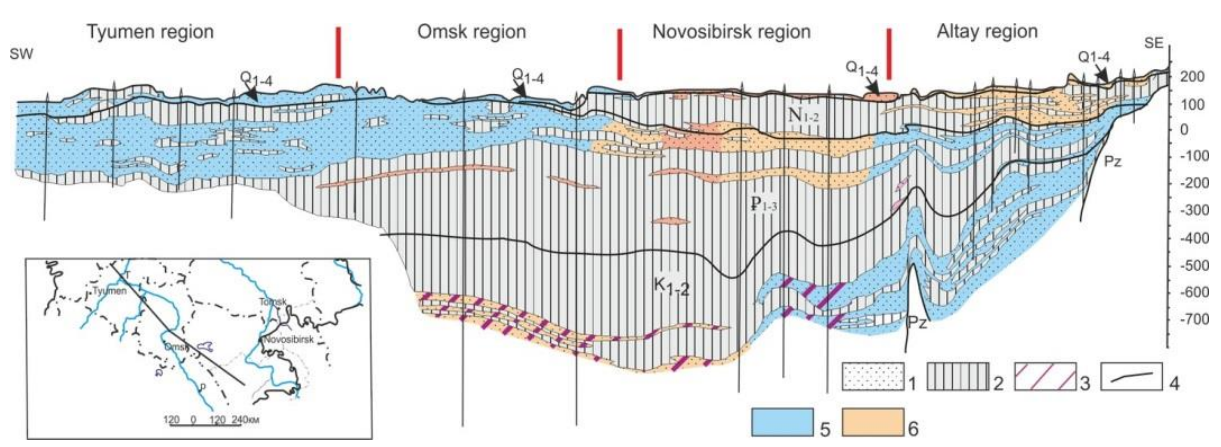

Fig.2 Cretaceous - Quaternary Hydrogeological Section of West Siberian Artesian Basin [5]

1. Water-bearing Deposits; 2. Water-proof Deposits; 3.Thermal and Subthermal (20$\left.50^{\circ} \mathrm{C}\right)$ Waters; 4.Stratigraphic Boundaries.5.Fresh Water; 6.Mineral Water. [9], central regions of Western Siberia are regarded as "promising" with water temperatures at the mouth of wells from 40 to $120^{\circ} \mathrm{C}$, areas on the periphery of the basin are "with limited prospects" with water temperatures at the mouth of the wells from 20 to $40^{\circ} \mathrm{C}$. Maximum temperatures up to $100{ }^{\circ} \mathrm{C}$ and more are observed in internal depressions. The Cenomanian water-bearing complex $\left(\mathrm{K}_{1-2}\right)$ has the best hydro-geological parameters (depth, rate, mineralization, temperature) for geothermal raw materials for Western Siberia. Its permeable part is confined to the Pokur formation and its analogs. The depth of the 
complex roof is from 150 to $1300 \mathrm{~m}$, the total thickness is from 200 to $800-1000 \mathrm{~m}$. The water pressure in most of the basin is $20-40 \mathrm{~m}$ above the drill mouth, the water temperature is + 30-43 0C, self-discharge rate is $10-251 / \mathrm{s}$ [1]. Such subthermal waters cannot be directly used in hot water supplying and heating systems. The use of geothermal systems makes it possible to expand the prospects of the subsoil thermal power potential.

Geothermal systems include a wide variety of designs and operations(see, for example, [10]). If groundwater is considered as a source of energy for heating a structure they are usually called groundwater-source heat pumps ( GSHP). These days GSHP systems are one of the most widespread "green" technologies for heating and cooling of buildings. An overview of the current state-of-the-art, latest developments and trends in GSHP system technology can be found at [11]. Unfortunately, for a number of reasons, as it will be shown later, in Western Siberia and Russia in general, the use of geothermal systems is extremely limited.

\section{Analysis of geothermal energy use in Western Siberia}

In Western Siberia the direct use of thermal waters (with the formation temperature of 40$100{ }^{\circ} \mathrm{C}$ and mineralization of 1-5 g/1) is practiced in the Tyumen, Tomsk, Novosibirsk and Omsk regions for balnearies. In agriculture these waters are used in fish farming (wintering ponds) and greenhouse production.

Since the 1980s regional programs for assessing the resources of hydrothermal waters have been operating in a number of administrative areas in the southern part of Western Siberia. In the Novosibirsk region the regional target program "Introduction of heat pumps at fuel and energy complex facilities on the territory of the Novosibirsk Region for 1999 2002" was adopted. Based on this program "perspective" and "very promising" objects were chosen in 26 settlements of the region where heat pumps could be installed.As of 01.01.2003, heat pumps operated in 6 settlements using groundwater resources of the Cretaceous Aquiferous Complex $\left(\mathrm{K}_{1-2}\right)$. In Karasuktown a separately located building with the total square of $6,000 \mathrm{~m}^{2}$ (secondary school) has been heated by artesian water from a well with a temperature of $24{ }^{\circ} \mathrm{C}$ (at the mouth) for 25 years. The heat pump system consists of two GSHP systems NKT-300 manufactured by the Russian company "Energia"[12]. Its total heat output is $700 \mathrm{~kW}$. The facility was launched in 1992 . The cost of geothermal heat is about $40 \%$ of the cost of heat produced by coal boilers in the region; the payback period was 1.1 years [13]. Unfortunately, in the region these examples of heat pumps application are unique.

In the neighboring Omsk region the "Program for Development of Heat Power Resources in the Omsk Region for 2005 -2010" was developed and implemented. The aim of the Program was a balanced development of the mineral and raw materials base to meet the needs of the region in thermal energy of underground water resources. The main tasks were: to meet the needs of the region's population in thermal water and formation of mechanisms of state regulation in the sphere of research, reproduction, and use of the ground waters. The Program was financed both by the federal budget and by subsoil users. Unfortunately, because of not enough funding those very important tasks were reduced mainly to evaluation and inventory of geothermal water resources in three administrative districts of the region. Legal and economic aspects of the geothermal energy use have not been developed and implemented. The effectiveness of introducing geothermal systems into the Russian market can be demonstrated by the example of the Chuvash Republic. This administrative region is located in the European part of Russia with a temperate continental climate similar to the climate of the southern and central parts of Western Siberia. Favorable conditions for the introduction of heat pumps are created there. In 2002 for the first time in Russia the Cabinet of Ministers of the Chuvash Republic brought into effect 
separate energy tariffs. For energy generated by heat pumps the tariff is approximately 2.15 times lower than for energy produced by traditional heat supply systems. At the same time the use of heat pumps gives more than $70 \%$ fuel savings for heat supply of industrial buildings and public facilities [14]. Thus, even insignificant support from the state through tariffs regulation will allow the geothermal systems technology to take the firm place of gas and coal boilers on the market of heat-producing equipment.

\section{Conclusion}

The analysis of the thermal waters resource base in Western Siberia, makes it possible to draw the following conclusions. Geothermal energy of underground waters of Western Siberia, as a renewable ecologically clean natural resource, has been used successfully, but in a very limited scale, for the purposes of heat supply of social, agricultural objects and residential buildings, depending on the temperature of a heat source directly or with the use of GSHP systems.

Speedy development of the thermal power of groundwater must be achieved through the development and implementation of Federal targeted regional programs for the use of geothermal energy. These programs should be successors of regional programs that existed in some administrative regions of Western Siberia in recent decades. The main developers should be the Ministry of Natural Resources and Ecology of the Russian Federation, scientific and research institutes, R\&D firms. Financing of programs is possible partly by the federal budget, partly by subsoil users (public-private partnership).

Along with other positive moments, these measures will allow to solve the problems of sustainable heat supply of remote territories and improve their ecological situation.

\section{References}

1. O.V. Shiganova, Water: Ecology and Technology, Moscow, Russia, Vol.4 (2000)

2. V.P. Gavrilov, Forecast for Potential Trends of Russian and Global Energy Complex Development, Oil and Gas Geology, May 2016 (In Russian).

3. V. Svalova, K. Potapov, Geothermal Energy Use in Russia, Country Update for 20102015, World Geothermal Congress, Australia (2015)

4. O.V. Shiganjva, Y.Y. Marchenko, A.A. Shevchenko, Underground Waters of the South of Western Siberia (Russia) as a Source of Renewable Energy, Symposium on Thermal Science and Engineering in Serbia,Sokobanja,17-20, Vol.18 ${ }^{\text {th }}$ (2017)

5. Hydrogeology of the USSR, Vol. XVI, 1971 (In Russian).

6. A.E. Kontorovich, V.S. Surkov, West Siberia. Geology and Mineral Resources of Russia. Saint-Petersburg, Vol.2 (2000)

7. URL: http://www.gshp.org.uk/ground source heat pumps.html

8. J.D. Spitler, Latest Developments and Trends in Ground-Source Heat Pump Technology, European Geothermal Congress Strasbourg, France, 19-24 http://teplo.in/index.php/ob-ekty (2016)

9. Ju. M. Petin The Experience of a Heat Pumps Manufacturing Decade in CJSC (ZAO) "Energia", The Energy Policy, Vol.3, (2001)

10. V.P. Prochenko, V.G. Gorshkov, S.V.Osipovich, About the Experience of Heating Pumps Using in the Chuvash Republic, available online at: http://www.rosteplo.ru/tech_stat/stat_shablon.php?id=499. 